\title{
How do firms implement impairment tests of goodwill?
}

\author{
Plenborg, Thomas; Vriborg Petersen, Christian
}

Document Version

Final published version

Publication date:

2007

License

CC BY-NC-ND

Citation for published version (APA):

Plenborg, T., \& Vriborg Petersen, C. (2007). How do firms implement impairment tests of goodwill? Department of Accounting and Auditing, Copenhagen Business School.

Link to publication in CBS Research Portal

\section{General rights}

Copyright and moral rights for the publications made accessible in the public portal are retained by the authors and/or other copyright owners and it is a condition of accessing publications that users recognise and abide by the legal requirements associated with these rights.

Take down policy

If you believe that this document breaches copyright please contact us (research.lib@cbs.dk) providing details, and we will remove access to the work immediately and investigate your claim. 
Copenhagen

Business School

HANDELSHØJSKOLEN

WP 2007-02

How do firms implement impairment tests of goodwill?

by

Associate professor Christian Petersen

Professor Thomas Plenborg

Email: cp.acc@cbs.dk (Christian)

Email: tp.acc@cbs.dk (Thomas)

INSTITUT FOR REGNSKAB OG REVISION, Handelshøjskolen i København

Solbjerg Plads 3, C.4., 2000 Frederiksberg

TIf.: 38152320 Fax: 38152321

\section{DEPARTMENT OF ACCOUNTING AND AUDITING, Copenhagen Business School \\ Solbjerg Plads 3, C.4., DK-2000 Frederiksberg \\ Phone: +4538152320 Fax: +4538152321 \\ uk.cbs.dk/forskning_viden/institutter_centre/institutter/rr}

\section{Acknowledgements:}

We wish to thank Jeppe Christoffersen for valuable help in the process. 


\begin{abstract}
Adopting a survey approach, our study examines how firms implement impairment test of goodwill. We focus on how firms define and measure the recoverable amount of CGU. The survey includes 58 completed questionnaires representing $73 \%$ of the firms on the Copenhagen Stock Exchange that recognise goodwill in the balance sheet. Our survey generally supports that a common practice on impairment tests of goodwill has not yet been established. Based on our analysis it is difficult to determine whether this simply reflects that firms adopt an approach suited to their organisational and economic structures or if it exposes that firms are uncertain as how to apply a standard. The analysis also reveals that some of the methods used when defining a CGU are not in compliance with IAS 36. In addition, we find inconsistencies in the way that firms estimate the recoverable amount. Our analysis should be of interest to a number of parties including firms, financial advisors, auditors, standard setters and users of financial statements.
\end{abstract}

\title{
Key words:
}

Impairment tests, IAS 36, compliance, goodwill, value in use, valuation techniques. 


\section{How do firms implement impairment tests of goodwill?}

\section{Introduction}

In March 2004 the revised IAS 36 was approved by IASB. According to the revised IAS 36 firms must carry out impairment test of goodwill on at least a yearly basis. If the recoverable amount of goodwill is less than its carrying amount, the carrying amount shall be reduced to its recoverable amount (e.g., an impairment loss is recognised). IAS 36 defines the recoverable amount as the higher of an asset's value in use and fair value less costs to sell. This is a radical change in accounting for goodwill. Previously, international accounting standards required recognition of goodwill subject to amortisation over its useful life time.

We conduct a descriptive study that examines how Danish companies implement the revised IAS 36. We also evaluate what firms do in cases where IAS $36^{1}$ provides little or no specific guidance. We focus on two issues in IAS 36 that have received attention in the literature: a) how firms define a cash generating unit (CGU) and b) how those firms measure the recoverable amount of a CGU. We focus on technical aspects related to carrying out impairment tests of goodwill. For instance, we examine how firms calculate cost of capital and how terminal value is estimated in calculating the recoverable amount. However, we do not address if estimates seem fair ${ }^{2}$.

An empirical examination of how firms implement impairment test of goodwill seems warranted. First, while prior research (see e.g. Henning et al 2000; Jennings et al 2001; Bugeja and Gallery, 2006) examine the information content of goodwill and goodwill amortisation (the correlation between accounting numbers for goodwill and market data ([stock prices and stock returns]), we examine how firms implement impairment test of goodwill. Anderson (2004) argues that the new and revised standards on business combinations and intangible assets respectively, have been well documented but there has been little discussion on how these requirements will be followed in practice.

Second, IAS 36 is a standard that involves a great deal of judgement. An example is the identification of an asset's cash generating unit (IAS 36, 68). Further, while value in use is one of

\footnotetext{
${ }^{1}$ In cases where no recommendations are provided in IAS 36 we include recommendations from related literature.

${ }^{2}$ An analysis of the estimates that are the foundation for the impairment test is at least as important. For demarcation reasons we have chosen to focus on the technical aspects of IAS 36.
} 
the measurement concepts in IAS 36, the standard is silent as to how various value drivers should be estimated. For example, IAS 36 does not provide a guidance that explains how terminal value should be measured. In addition, IAS 36 deviates from 'traditional' valuation practice on certain issues. A prime example is IAS 36, 55 that requires discount rates to be pre-tax rates. ${ }^{3}$ In fact, this policy is questioned by whose who responded to the exposure draft on IAS 36, who raise concerns in regard to using pre-tax discount rates (IAS 36, BC91). Petersen et al. (2006) provide evidence that discount rates in practice are estimated on an after-tax basis. This approach is also supported by a number of popular valuation text books such as Koller et al (2005) and Damodaran (2002).

Finally, IAS 36 is a complicated standard that requires special knowledge about valuation techniques. Producers of accounting information (firms) and their financial advisers must possess the necessary technical skills (e.g. be able to apply valuation models) and economic expertise (e.g. make fair budget assumptions) that is needed to carry out impairment tests. These skills are needed, as auditors may not assist in such valuation work under strict ethical and independence rules (Anderson, 2004).

Many argue that an impairment test only approach seems a logical step in the development of accounting for goodwill. First, the underlying logic for removing the traditional amortisation methodology is that the amortisation on a straight-line basis over a number of years contains no information value for those using financial statement (Ravlic, 2003). Moreover, IFRS 3 no longer requires that companies perform the almost impossible task of estimating the useful life for goodwill (Jansson et al., 2004). Second, the impairment approach should provide users of financial statements with better information, as goodwill is not automatically amortised (Colquitt and Wilson, 2002). Finally, goodwill impairment tests would be operational and capture a decline in value of goodwill (Donnelly and Keys, 2002).

On the other hand, the new approach in accounting for goodwill may be questioned on several grounds. First, while amortisation of goodwill is considered to be arbitrary, it is easy to apply in comparison with the impairment approach. The major benefit of amortisation of goodwill on a straight line basis is that it is possible with a greater accuracy to predict the impacts of earnings. (Stevenson and McPhee, 2005). This is in line with Lachnit and Müller (2003) who argue that to

\footnotetext{
${ }^{3}$ IAS 36, BC94 acknowledges that discounting post-tax cash flows at a post-tax discount rate and discounting pre-tax cash flows at a pre-tax discount rate should give the same result.
} 
achieve comparability among firms, adjustments for different accounting practices are necessary. Among the different kinds of treatment of goodwill, they regard the amortisation of goodwill over a predetermined time horizon as the most useful practice. Only by amortizing goodwill on a systematic basis is it possible to determine "normalized" or "permanent" income as a measure of earnings power. Second, conducting a detailed test for impairment on every asset and associated goodwill from initial acquisition at the end of each reporting period may be time consuming and costly (Mcgeachin, 1997; Rockness, Rockness and Ivancewich, 2001). Third, the European Financial Reporting Advisory Group (EFRAG) in their comments to IFRS 3 expresses "major concerns" over IFRS 3. EFRAG argue that the standard would introduce unreliable measurements of the recoverable amount of goodwill.

In light of the above, we find it relevant to examine how Danish firms implement impairment tests of goodwill. To do so we send out questionnaires to every Danish listed company that reports goodwill. ${ }^{4}$ Thereby, we obtained a unique dataset that provides in dept information concerning how impairment test of goodwill is carried out in practice. Our results indicate that a common practice has not yet been established. Further, some firms do not define a CGU in compliance with IAS 36. Finally, we find inconsistencies in the way that firms estimate the recoverable amount. Areas of concern include calculating the before-tax discount rate, adjusting for risk, and estimating the cash flow in the terminal period.

Since international accounting standards have been adopted by listed firms in several countries our results should be of interest for a large number of firms, auditors, standard setters and users of financial statements. For example, Australia and New Zealand adopted the international accounting standards on 1 January 2005 and 1 July 2007, respectively, and listed firms in both countries have to comply with the same accounting standards as the listed Danish firms. ${ }^{5}$ Among other things, we believe that our results will serve as a guidance to improve current practice - especially in areas where firms seem to have difficulties in carrying out impairment test properly.

Our paper continues as follows. Section 2 presents a brief overview of how goodwill is accounted for. A description of the methodology, sample, and descriptive statistics follow in sections 3 and 4.

\footnotetext{
4 Software to our internet based questionnaire has been provided by Enalyzer.

${ }^{5}$ Please refer to Banghøj and Plenborg (2007) for a comparison of the Australian, New Zealand and Danish accounting regulations and corporate governance systems.
} 
Section 5 presents the results of how firms determine a CGU, while section 6 presents the empirical findings of how firms apply valuation techniques used for impairment testing purposes. Finally, section 7 presents conclusions and perspectives for further research.

\section{Accounting for goodwill under IFRS 3 and IAS 36}

IFRS 3, 36 requests that acquired assets, liabilities and contingent liabilities are recognised at fair value in the annual accounts of the acquiring firm, if they comply with recognition criteria, regardless of whether they have been recognised previously. IFRS 3 requires that to the extent the purchase price exceeds the total fair value of the identifiable net assets this difference is recognised as goodwill. IFRS 3 does not permit amortisation of goodwill but requires goodwill to be tested for impairment as set forth in IAS 36.

IAS 36 demands that each separate asset is tested for impairment, if there are indications of impairment. Assets with an indeterminable lifetime, which are not amortised, must be tested for impairment at least on a yearly basis. Goodwill cannot be tested separately, as it represents resources that cannot be identified or quantified reliable. Goodwill is therefore allocated to the individual CGU or group of CGUs that benefit from the acquired goodwill (IAS 36, 80). If the recoverable amount of the CGU that goodwill is allocated to is lower than the carrying value of that unit the difference is expensed. If this difference is greater than the carrying amount of goodwill, the total goodwill amount is written off, while the remaining difference is allocated to (subtracted from) the remaining assets on a pro rata basis (IAS 36). ${ }^{6}$

The recoverable amount for an asset, CGU or group of CGUs is the higher of that its fair value less costs to sell and its value in use. Applying value in use of a CGU is problematic. Discounted cash flow calculations have previously been applied to financial assets and liabilities, where the expected future cash flows to a much larger extend is a good proxy for the future realized cash flows than will be the case for discounted cash flow calculations used to test for impairment.

\section{Research design}

\footnotetext{
${ }^{6}$ Apart from cash and cash equivalents etc.
} 
We adopt a survey-based analysis to examine how Danish firms define a CGU and estimate the recoverable amount in carrying out impairment tests of goodwill. Given the descriptive nature of our study, surveys seem superior to other research methods [Yin (1994)]. Surveys complement other research methods based on either large samples or case studies. As pointed out by Graham and Harvey (2001), large studies are the most common type of empirical analysis offering statistical power and cross sectional variation. On the other hand, large sample studies have the weakness related to variable specification and the inability to ask qualitative questions. Case studies offer details and unique information regarding corporate behaviour, however such samples are small and results are often sample-specific. Surveys as adopted in this study offer a balance between large studies and case studies. We obtain a larger sample than in case studies, improving the validity. Further, we are able to ask detailed questions, which improve the quality of the data. Surveys (questionnaires) are not without potential problems, however. Surveys face the risk that the respondents are not representative of the population and that the questions are misunderstood. Each of these issues is addressed below.

Based on a careful review of IAS 36 and related literature, we developed a draft questionnaire that focuses on a) identifying a CGU and b) measuring the recoverable amount of a CGU. The draft questionnaire was circulated to auditors from leading auditing firms and CFOs employed at large Danish firms. We incorporated their suggestions in the revised questionnaire. Further, we sought advice from colleagues that have specialised in surveys and received valuable feedback on design issues and ideas as how to increase the response rate. As a final test the questionnaire was mailed to four firms, which resulted in additional modifications of the questionnaire.

\section{Sample and descriptive statistics}

To identify firms that carry goodwill in the balance sheet, we collected data form Account Data, a database that record accounting data from Danish listed firms. 80 out of a 165 firms that were listed on the Copenhagen Stock Exchange as of March 1, 2006 recognised goodwill as assets. ${ }^{7}$

\footnotetext{
${ }^{7}$ Account Data listed 82 firms recognising goodwill as of March 1, 2006. However, at the time we contacted those firms two of them no longer recognised goodwill.
} 
Each of those 80 firms was contacted by phone in order to identify the person in charge of impairment testing. ${ }^{8}$ Personal contacts served two purposes. First, we wanted to make sure that the questionnaire was mailed to the right person (i.e., the one deeply involved in impairment testing). Second, the personal contacts would enable us to make follow up phone contacts either to remind respondents to fill in the questionnaire or for clarification purposes. Four of the 80 firms did not wish to participate in the survey. An internet based questionnaire was submitted to the remaining 76 firms. The link was forwarded directly to the person in charge of impairment tests. The respondents also received a letter describing the purpose of the survey. After approximately three (six) weeks, a reminder was e-mailed to the persons that had not yet filled in the questionnaire. Finally, after another couple of weeks, we called the firms that had still not completed the questionnaire and encouraged them to do so.

58 firms responded to every single question in the questionnaire. An additional four firms submitted usable feedback that were sufficient, although a few questions were left unanswered, leaving a final sample of 62 observations. Launsø and Rieper (2000) argue that feedback from at least $70 \%$ is sufficient to provide a picture of the population. Our questionnaire was filled in by $72.5 \%$, while additionally $5 \%$ of the respondents provided feedback on the major part of the questionnaire. ${ }^{9} \mathrm{~A}$ feedback rate of over $70 \%$ is quite unusual for questionnaires.

In order to check the validity of the data (filled in questionnaire) we received, we contacted the respondents, who had permitted us to do so, and asked them to elaborate on their data and provide any further information they might have. This additional check didn't change the general results as reported in the following sections.

\section{Descriptive statistics}

More than two-thirds of the firms have a turnover of DKK $0-5$ billion and total assets amounting to DKK $0-10$ billion. The largest firms have a turnover in excess of DKK 45 billion and assets of more than DKK 90 billion. Goodwill is a significant item ranging from DKK 1 million to DKK 28.5 billion. On average, goodwill amounts to $6 \%$ of total assets. In one case, goodwill total approximately one-third of assets.

\footnotetext{
${ }^{8}$ In almost all cases the CFO was the contact person.

${ }^{9}$ As $78 \%$ of all listed firms that recognise goodwill are part of our study, we believe that representativeness is not an issue (selection bias).
} 
On average (median) firms report DKK 1.280 (88) million in goodwill. This indicates that a few firms recognise considerable goodwill amounts.

\begin{tabular}{|c|c|c|c|c|c|c|c|c|c|c|c|}
\hline \multicolumn{11}{|c|}{ Table 1: Firm characteristics } & \multirow[t]{2}{*}{ Answers } \\
\hline \multirow{2}{*}{ Turnover (billion DKK) } & $0-5$ & $5-10$ & $10-15$ & $15-20$ & $20-25$ & $25-30$ & $30-35$ & $35-40$ & $40-45$ & $>45$ & \\
\hline & $69 \%$ & $15 \%$ & $6 \%$ & $3 \%$ & $2 \%$ & $0 \%$ & $2 \%$ & $2 \%$ & $0 \%$ & $2 \%$ & 62 \\
\hline \multirow[t]{2}{*}{ Assets (billion DKK) } & $\overline{0-10}$ & $10-20$ & $20-30$ & $30-40$ & $40-50$ & $50-60$ & $60-70$ & $70-80$ & $80-90$ & $>90$ & \\
\hline & $76 \%$ & $8 \%$ & $0 \%$ & $2 \%$ & $8 \%$ & $0 \%$ & $2 \%$ & $0 \%$ & $0 \%$ & $5 \%$ & 62 \\
\hline \multirow[t]{2}{*}{ Goodwill (billion DKK) } & $\overline{0-0,2}$ & $0,2-0,4$ & $0,4-0,6$ & $0,6-0,8$ & $0,8-1,0$ & $1,0-1,2$ & $1,2-1,4$ & $1,4-1,6$ & $1,6-1,8$ & $>1,8$ & \\
\hline & $74 \%$ & $6 \%$ & $3 \%$ & $3 \%$ & $3 \%$ & $0 \%$ & $2 \%$ & $0 \%$ & $0 \%$ & $8 \%$ & 62 \\
\hline \multirow[t]{2}{*}{ No. of subsidiaries } & $0-10$ & $11-20$ & $21-30$ & $31-40$ & $41-50$ & $51-60$ & $61-70$ & $71-80$ & $81-90$ & $>91$ & \\
\hline & $42 \%$ & $16 \%$ & $10 \%$ & $3 \%$ & $6 \%$ & $3 \%$ & $6 \%$ & $3 \%$ & $2 \%$ & $8 \%$ & 62 \\
\hline
\end{tabular}

Most firms make on average 0-4 firm acquisitions per year (not reported). ${ }^{10}$

Table 2 panel A uncovers that impairment tests typically is carried out by one or more persons from headquarter. This is the case in 47 of the firms. For 14 firms impairment tests is carried out in a teamwork involving the centralized and decentralized level. None of the participating firms carry out impairment tests exclusively on a decentralized level. This indicates that utilizing an impairment test is a complicated exercise requiring special know how. These competences are often found at the centralized level (headquarter) only. Table 2 panels $\mathrm{B}$ and $\mathrm{C}$ illustrate that it is mostly persons within the firm that carry out impairment tests, while12 firms receive external assistance by an auditing firm. In $52(20+19+13)$ of the participating firms, the persons who are involved in impairment tests are partly or often engaged in other valuation tasks (Table 2 panel D). In six (5+1) firms the person(s), who is involved in impairment tests, is not active in other valuation tasks. As there is a considerable overlap in the competences that are required to carry out impairment tests and other valuation tasks (typically acquisitions of firms), it would seem more appropriate to involve the same resource person(s). Often the methods used for valuation will be similar and assumable there will also be a considerable overlap in budgeting.

\footnotetext{
${ }^{10}$ Not all results are reported for reasons of space.
} 


\begin{tabular}{|l|c|}
\hline Table 2 & \\
\hline Panel A & No. \# \\
How are impairment tests carried out? & 47 \\
\hline By a central or central placed person & 14 \\
\hline In a cooperation between decentralized and centralized levels & 0 \\
\hline Outsourced to decentralized levels & 1 \\
\hline Don't know / does not wish to answer & 62 \\
\hline Total & \\
\hline
\end{tabular}

\begin{tabular}{|l|c|}
\hline Panel B & No. \# \\
Who caries out impairment tests at the group level? & 12 \\
\hline One internal expert & 36 \\
\hline A team of internal experts & 0 \\
\hline External expert(s) & 12 \\
\hline Internal and external experts & 0 \\
\hline Don't know / does not wish to answer & 60 \\
\hline Total & \\
\hline
\end{tabular}

\begin{tabular}{|l|c|}
\hline Panel C & No.\# \\
Which of the following terms best describes the external experts? & 12 \\
\hline Audit firm & 0 \\
\hline Corporate Finance firm & 0 \\
\hline Consulting firm & 0 \\
\hline Don't know / does not wish to answer & 0 \\
\hline Other (please specify in the textbox below) & 12 \\
\hline Total & \\
\hline
\end{tabular}

\begin{tabular}{|l|c|}
\hline $\begin{array}{l}\text { Panel D } \\
\text { On a scale from 1 to 5, in to what extent are people who carry out } \\
\text { impairment tests involved in other valuation jobs (1 means "Not at all", } \\
\text { while 5 equals "To a very large extent")? }\end{array}$ & No. \# \\
\hline Don't know / does not wish to answer & 3 \\
\hline 1 & 1 \\
\hline 2 & 5 \\
\hline 3 & 13 \\
\hline 4 & 19 \\
\hline 5 & 20 \\
\hline Total & 61 \\
\hline
\end{tabular}




\section{Cash generating units}

\section{Defining a CGU}

A CGU (cash generating unit) is the smallest group of identifiable assets that generates cash flows independent of cash flows from other assets or group of assets (IAS 36, 6). Ernst \& Young (2006) notes that determining CGUs is not easy in practice. Also, IAS 36, 68 concedes that determining a CGU involves judgments. IAS 36, 80b states that a unit or group of units shall not be larger than an operating segment determined in accordance with IFRS 8 (operating segments). Despite of this IAS 36 provides limited guidance in how to settle on a CGU. Deciding what constitutes a CGU, however, has an impact on the need to recognise impairment losses. Evidently the need to write-off depends upon the number of CGUs. Based on empirical research of the largest firms in Europe, Ernst \& Young $(2006,35)$ conclude that in practice a firm recognises one CGU for each of its segments, even though firms do not specifically disclose it.

\begin{tabular}{|c|c|}
\hline $\begin{array}{l}\text { Table } 3 \\
\text { Which of the following statements describes the relation between the } \\
\text { number of CGUs and the number of segments (in accordance with IFRS } \\
8) \text { ? }\end{array}$ & No. \# \\
\hline No of CGUs $=$ no. of segments & 15 \\
\hline No of CGUs $<$ no. of segments & 5 \\
\hline No of CGUs $>$ no. of segments & 36 \\
\hline Don't know / do not wish to answer & 6 \\
\hline Total & 62 \\
\hline
\end{tabular}

The results in Table 3 illustrate, however, that only approximately $25 \%$ of the firms (in our sample) use a segment to represent a CGU. The main number of firms (36) has more CGUs than segments as defined in IFRS 8. Five firms operate with fewer CGUs than segments, which is a violation of IAS $36,80 \mathrm{~b}$. The number of CGUs varies considerably across firms (not reported). There is on average (median) 16 (5) CGUs per firm. A few firms have one CGU per firm only, while one firm operates with 200 CGUs. On average (median) the turnover is DKK 838 (399) million per CGU, while there is a spread from DKK 12 million to DKK 10 billion.

The statistics expose a great variety in the way CGUs are determined, which may impact the need for recognising impairment. From a user perspective this is not appropriate, as it complicates comparison of accounting data and financial ratios across firms. 


\begin{tabular}{|c|c|c|c|c|c|c|c|c|}
\hline $\begin{array}{l}\text { Table } 4 \\
\text { Grade on a scale from } 1 \text { to } 5 \text { the extent to which each of the } \\
\text { following statements describe the deciding factor for } \\
\text { determining the number of CGUs ( } 1 \text { means } \\
\text { "Not at all", while } 5 \text { means "To a very high degree") }\end{array}$ & $\begin{array}{l}\text { Don't } \\
\text { know/ do } \\
\text { not wish to } \\
\text { answer }\end{array}$ & 1 & 2 & 3 & 4 & 5 & Total & No. \# \\
\hline $\begin{array}{l}\text { The internal reporting systems determines how small a CGU } \\
\text { may be }\end{array}$ & $3 \%$ & $29 \%$ & $18 \%$ & $18 \%$ & $15 \%$ & $18 \%$ & $100 \%$ & 62 \\
\hline $\begin{array}{l}\text { A large number of CGUs will bring about a considerable } \\
\text { number of impairment tests and thereby make impairment } \\
\text { tests less operational }\end{array}$ & $8 \%$ & $19 \%$ & $10 \%$ & $26 \%$ & $24 \%$ & $13 \%$ & $100 \%$ & 62 \\
\hline $\begin{array}{l}\text { CGUs must be in accordance with segments (in accordance } \\
\text { with to IFRS 8) }\end{array}$ & $16 \%$ & $23 \%$ & $23 \%$ & $13 \%$ & $15 \%$ & $11 \%$ & $100 \%$ & 62 \\
\hline The number of write-offs should be hold at a minimum & $6 \%$ & $24 \%$ & $31 \%$ & $21 \%$ & $11 \%$ & $6 \%$ & $100 \%$ & 62 \\
\hline Cash flows from the CGUs must be independent of each other & $5 \%$ & $6 \%$ & $5 \%$ & $26 \%$ & $35 \%$ & $23 \%$ & $100 \%$ & 62 \\
\hline Other (please specify in the textbox below if relevant) & $92 \%$ & $2 \%$ & $0 \%$ & $2 \%$ & $2 \%$ & $3 \%$ & $100 \%$ & 62 \\
\hline
\end{tabular}

Table 4 illustrates what determines the number of CGUs. At least two statements seem to be a deciding factor. The statement that 'a large number of CGUs will bring about a considerable number of impairment tests and thereby make impairment tests less operational' indicates that firms are pragmatic. The other statement that 'Cash flows from the CGUs must be independent of each other' is in line with IAS 36, 68. For some firms the internal reporting systems resolve how small a CGU might be. A few firms argue that the number of CGUs must be in accordance with segments (IFRS 8) or be decided based on the wish to reduce the number of write-offs. Especially the later argument is inappropriate, as firms speculate how to reduce the need for write-offs rather than establishing CGUs based on the standard's indicators (e.g., that cash flows in CGUs must be independent of each other).

\section{Allocation of goodwill}

To carry out impairment tests on the CGU-level, in accordance with IAS 36, 80, purchased goodwill must be allocated to the respective CGUs that are assumed to benefit from synergies from the acquisitions. ${ }^{11}$

\footnotetext{
${ }^{11}$ IAS 36, IN11 state that "each unit and group of units to which goodwill is allocated should not be larger than a segment based on either the entity's primary or the entity's secondary reporting format determined in accordance with IAS 14 Segment Reporting". Due to special circumstances we have not been able to examine unambiguous, if firms act in accordance with this condition.
} 

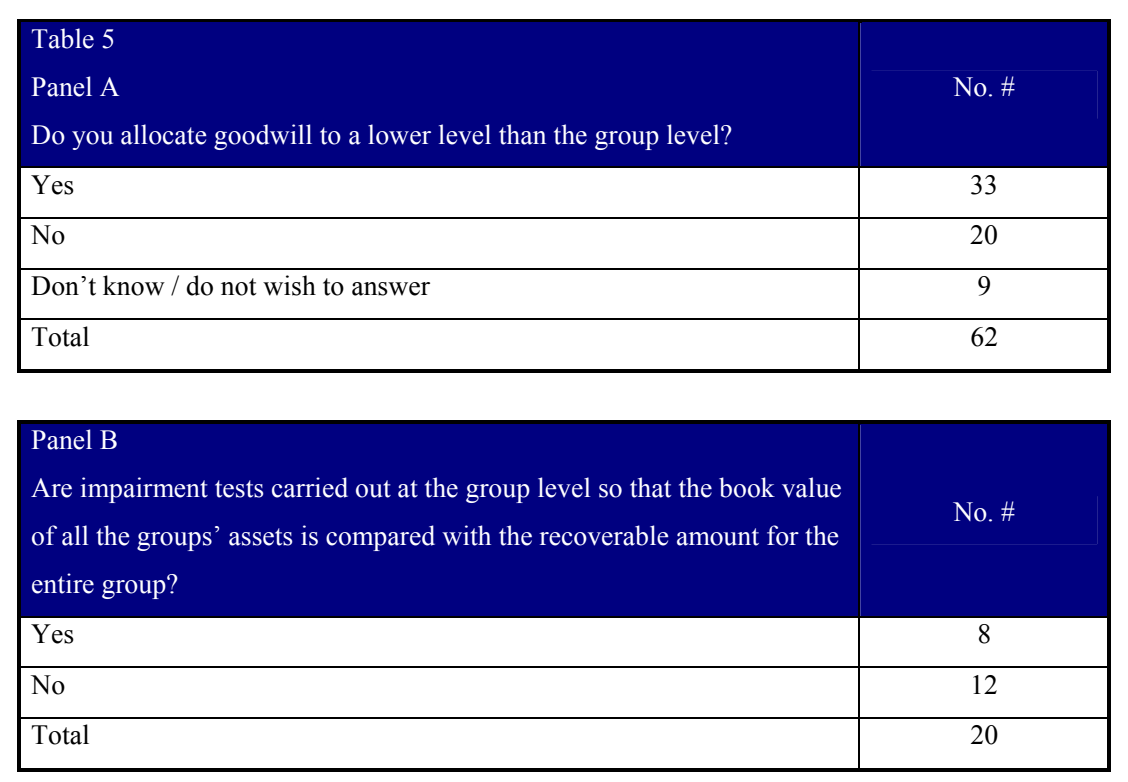

\begin{tabular}{|l|c|}
\hline Panel C & \\
Please specify the key to allocation of goodwill to CGUs (more than one & No. \# \\
answer is permitted): & 6 \\
\hline $\begin{array}{l}\text { The likely increase in value creation that the acquisition is expected to } \\
\text { provide }\end{array}$ & 5 \\
\hline $\begin{array}{l}\text { Turnover, assets, equity (or other accounting items) in the CGUs, which } \\
\text { goodwill is allocated to }\end{array}$ & 12 \\
\hline $\begin{array}{l}\text { Allocation of the acquired firms turnover, assets, equity (or other } \\
\text { accounting items) to CGUs }\end{array}$ & 7 \\
\hline Don't know / do not wish to answer & 7 \\
\hline Other (please specify in the textbox below) & 37 \\
\hline Total & \\
\hline
\end{tabular}

Table 5 panel A shows to which level, goodwill is allocated. 33 of the participating firms allocate goodwill to a lower level than the group level. 20 firms do not allocate goodwill to a lower level than the group level. In their verbal comments firms, which do not allocate goodwill to a lower level than the group level, argue that they wish to make impairment tests operational.

If firms do not allocate goodwill, IAS 36 requires that an impairment test on the group level must be carried out. Table 5 panel B reveals, however, that only eight out of 20 firms carry out impairment tests on the group level. The result that 12 firms apparently do not carry out impairment test - even at the group level - is puzzling. A possible explanation might be that goodwill is immaterial. However, our data does not support that this is the case. The level of goodwill deflated by total assets for the 12 firms corresponds to the level of goodwill for the remaining sample. An alternative 
explanation might be that the respondents do not distinguish between a full-dress impairment test and the more 'casual' one as described in IAS 36, 99. ${ }^{12}$

Theoretically, goodwill should be allocated to a CGU or group of CGUs, which are expected to receive the economic benefits from the acquired activity. This is also required by IAS 36, IN11 which states that 'goodwill should.... be allocated to each of the acquirer's CGU, or groups of CGUs, that are expected to benefit from the synergies of the business combinations, irrespective of whether other assets or liabilities of the acquiree are assigned to those units or groups of units'.

Table 6 panel $\mathrm{C}$ presents the allocation keys that are used to allocate goodwill in practice. Six firms determine the allocation of goodwill based on the estimated value creation each CGU is expected to generate, which is in accordance with IAS 36. Most often, the size of the acquired firms turnover and assets that are recognised in each CGU or group of CGUs, are used as the criteria for allocation of goodwill. If allocation of goodwill is based on turnover or assets, the CGU, which 'receives' turnover and assets, must also receive the benefits from the pooling of the firms. As illustrated in IAS 36, IN11 above, this is not necessarily always the case. Seven firms answer 'other' and the verbal comments indicate that allocation of goodwill is not a problem, as goodwill is recognised in the CGU that is affected by the acquisition (and, thus, need not to be allocated).

\section{Allocation of corporate assets}

Corporate assets (for example a head quarter, a common research center and common support facilities) may be problematic in relation to impairment tests of goodwill. IAS 36, 102 states that corporate assets must be allocated to individual CGUs. In the event that this is not possible, impairment tests should be carried out at a higher level (group of CGUs), to which it is possible to allocate corporate assets. As it might be difficult to allocate corporate assets to a CGU or group of CGUs in 'a reasonable and consistent way' (IAS 36, 102), it is likely that many firms choose not to do so.

\footnotetext{
${ }^{12}$ If this is the explanation for our finding, one may question if those 12 firms are the ones that generally provide inconsistent answers to our survey. However, a closer review of the feedback from the respondents reveals that it is not the same firms that provide inconsistent answers throughout the questionnaire.
} 

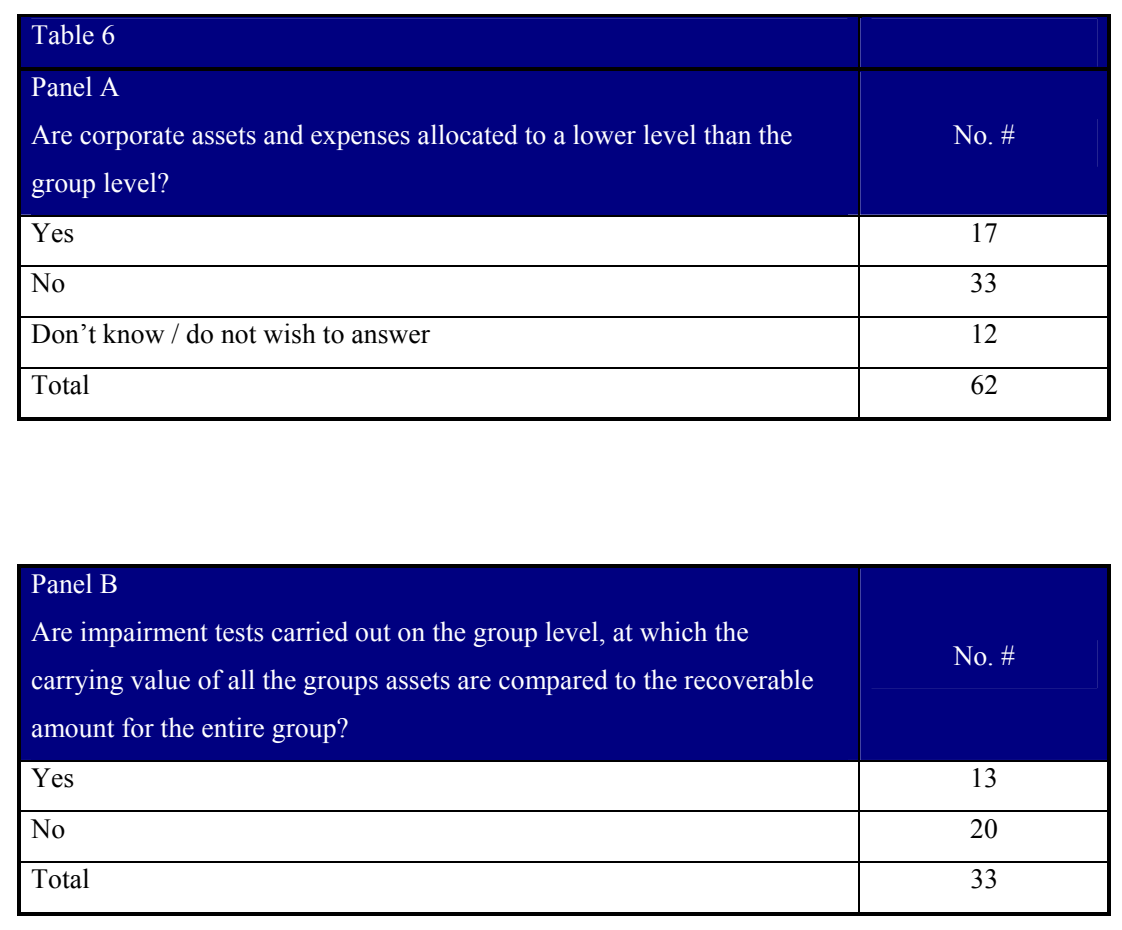

Table 6 panel A confirms this prediction. 33 firms do not allocate corporate assets to a lower level than group level, while only 17 firms do so. The 33 firms that do not allocate corporate assets to a lower level than group level, should carry out impairment tests on the group level cf. IAS 36, 102 iii. The results (Table 6 panel B), however, prove that only 13 of the 33 firms carry out impairment tests on the group level. As a consequence firms may not recognise impairment losses to the extent that they should.

\section{Method to estimating the recoverable amount}

\section{Choice of valuation approach}

A central element in impairment tests is estimating the recoverable amount. The assets' carrying value is compared with the recoverable amount and an impairment loss is recognised, if the recoverable amount is lower. In accordance with IAS 36, 18 the recoverable amount is the higher of its fair value less costs to sell and its value in use. 


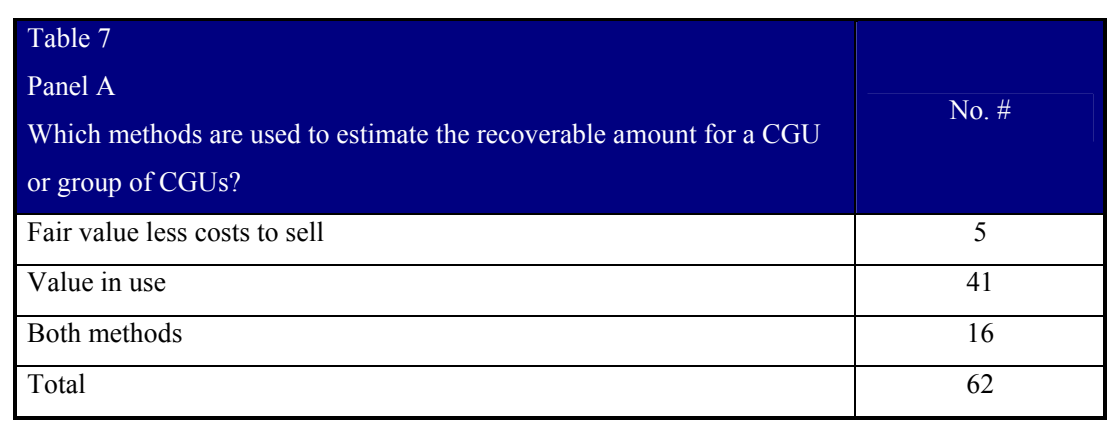

\begin{tabular}{l|c|}
\hline $\begin{array}{l}\text { Panel B } \\
\text { When fair value less costs to sell is estimated, which of the following } \\
\text { situations will the calculations be based on (more than one answer } \\
\text { permitted)? }\end{array}$ & No. \# \\
\hline An offer to acquire the CGU exist & 9 \\
\hline The CGU or the group of CGUs are listed on a stock exchange & 6 \\
\hline A comparable firm has recently been bought/sold (multiple) & 7 \\
\hline A comparable listed firm exist (multiple) & 4 \\
\hline Don't know / do not wish to answer & 4 \\
\hline Other (please specify in the textbox below) & 0 \\
\hline Total & 30 \\
\hline
\end{tabular}

\begin{tabular}{|l|c|}
\hline $\begin{array}{l}\text { Panel C } \\
\text { Which of the following methods are used to estimate value in use in } \\
\text { relation to impairment tests (more than one answer permitted)? }\end{array}$ & No. \# \\
\hline DCF-model (Discounted Cash Flow-model) & 56 \\
\hline EVA-model (Economic Value Added-model) & 2 \\
\hline Multiples & 9 \\
\hline Other (please specify in the textbox below) & 1 \\
\hline Total & 68 \\
\hline Number of respondents & 57 \\
\hline
\end{tabular}

Table 7 panel A exposes that it is primarily value in use that is applied in determining the recoverable amount. Only five firms use fair value less costs to sell. 16 firms use this method in combination with value in use. Other firms (41) apply the value in use method exclusively. A possible explanation for the limited use of fair value (less costs to sell) is that the method necessitates that the market value of the CGU is known. It requires, in reality, that the CGU is a listed firm or (reliable) indicators of the market value are available.

Table 7 panel B shows which methods firms apply in order to estimate fair value. In nine cases fair value is based on an offer from a third party to buy the CGU. In six cases the CGU is listed on a stock exchange, while in 11 cases a comparable firm's price formation is used to estimate fair value. Finally, Table 7 panel B provides evidence that in a number of cases more than one method is 
applied (total responses is greater than the number of respondents) in order to determine fair value (less costs to sell) of a CGU. This seems appropriate considering the uncertainty involved in the estimation of the value of a CGU.

\section{Methods to calculate value in use}

In estimating the value in use IAS 36, 30 suggests the application of the discounted cash flow model (DCF). Out of the 57 firms that apply the value in use method to determine the recoverable amount, 56 firms apply the DCF model (Table 7 panel C). In addition, the EVA model (2) and multiples (9) are applied. These methods are often used as a 'sanity check'. ${ }^{13}$ The one firm applying another method ('other'), seems to use a variant of the DCF model. Of the nine firms that use multiples, P/E (3) and EV/EBIT (3) ${ }^{14}$ are the most popular (not reported). As the P/E multiple estimates market value of a CGU's equity, it is only meaningful to use this multiple on financial firms. However, only one of the three firms that use P/E multiples is a financial firm (i.e., a bank). As value in use for the other two firms CGUs must be the estimated enterprise value (value of business independent of how it has been financed), it is unsuitable to use the P/E-multiple. If the market value of the (net) interest bearing debt is known for the individual CGU, it can be added to the value estimate based on $\mathrm{P} / \mathrm{E}$ to obtain the enterprise value. If the market value of interest bearing debt is unknown it will be difficult to estimate the enterprise value correctly.

When multiples are applied it is paramount to make sure that the comparable firms have identical 1) accounting practices, 2) expected future earnings growth, and 3) risks (See e.g. Damodaran 2002). Based on the responses, firms are aware of the requirements to future earnings and risks. On the other hand, only two firms actively examine differences in applied accounting practices. To the extent that accounting practices differ between the comparable firms, the estimated value will be biased (or at least if $\mathrm{P} / \mathrm{E}$ ratios are used as sanity checks, it might not be a meaningful way to check the validity of the estimated values).

An important element in applying the DCF model is to be confident that budget assumptions are based on sound economic reasoning. As an indicator of the thoroughness of the impairment tests, the firms were asked how much time they spent per impairment tests of goodwill. On average

\footnotetext{
${ }^{13}$ The feedback we received by calling respondents confirmed this fact.

${ }^{14}$ Where P, E, EV and EBIT are abbreviations for the market value of equity, net earnings, enterprise (value on a debt free basis) and earnings before interests and taxes.
} 
(median) 20 (8) hours were used per impairment tests (not reported). However, the spread is significant as two firms carry out impairment tests in about an hour, while one firm use 200 hours per impairment test. There is a positive correlation between the number of hours spent per impairment tests and the size of the CGU. The correlation coefficient is $65 \%$ (not reported). This indicates that more time is spent on larger (and presumably more complicated) CGUs, which is as expected. It is difficult based on the feedback to tell if sufficient time has been spent on budget assumptions. For instance, it might be enough to spend one hour if a budget for the CGU is already available (e.g., a budget prepared during the yearly strategic planning).

Petersen and Plenborg (2006) demonstrate that it is appropriate to use the same valuation model for every employee within the same group. It reduces the number of technical errors, makes maintenance easier, lower the reliance on specific persons and increases knowledge sharing and productivity among the firms' employees.

\begin{tabular}{|l||ccc|}
\hline Table 8 & $\begin{array}{c}\text { Panel A } \\
\text { Does the group have a common } \\
\text { discounted cash flow model that is } \\
\text { available in a spreadsheet or the like? }\end{array}$ & $\begin{array}{c}\text { Panel B } \\
\text { Is the common discounted cash }\end{array}$ & $\begin{array}{c}\text { Panel C } \\
\text { Is the same discounted cash flow } \\
\text { model used for impairment tests and } \\
\text { investment decisions? }\end{array}$ \\
\hline Yes & 42 & 39 & 19 \\
\hline No & 11 & 3 & 6 \\
\hline $\begin{array}{l}\text { Don't know / do not wish to } \\
\text { answer }\end{array}$ & 2 & 42 & 42 \\
\hline Total & 55 & 0 & 17 \\
\hline
\end{tabular}

Table 8 panel A reveals that a general discounted cash flow model is used by 42 of the participating firms. Eleven firms do not use the same discounted cash flow model. This indicates that these firms do not have a systematic way of developing a DCF model for impairment test. This may be problematic, as it increases the possibility that these firms commit technical errors. Of the 42 firms that apply the same discounted cash flow model, 39 had the model reviewed by its auditor (panel B). This, naturally, improves the probability that the impairment tests are error free.

The participating firms were asked if they use the same discounted cash flow model for impairment tests and investment decisions. Theoretically, there should be no differences between the two models, but as table 8 panel $\mathrm{C}$ reveals only 19 firms use the same discounted cash flow model for 
the two purposes. The respondents, who did not use the same model, gave different explanations. For example, several mentioned that "an investment decision is far more detailed and necessitates more assumptions and sensitivity checks". Others pointed out that "models used for impairment testing are carried out in accordance with IAS 36, which in some respects do not provide a business economics perspective and which, consequently, can be misleading". Unfortunately, the feedback was silent as to what constitutes those business economics differences. One respondent stated that 'different assumptions' are used for investment decisions and impairment tests. The motivation for applying different assumptions, however, was not provided.

\section{Before-tax or after-tax discount rates and cash flows}

IAS 36, 50, 51 and 55 specify that before-tax cash flows must be discounted with a before-tax discount factor. However, IAS 36, BC94 acknowledges that, conceptually, discounting post-tax cash flows at a post-tax discount rate or discounting pre-tax cash flows at a pre-tax discount rate should give the same results. Even though the estimated value should be insensitive to the choice of a before tax respectively an after tax calculation, most academic books (e.g., Koller et al, 2005) estimate value in use on the basis of after-tax cash flows, discounted by an after-tax discount rate. An after tax calculation takes into consideration that firms pay tax on earnings from operations. In return firms benefit tax savings due to interest expenses on its debt.

IAS 36 is not explicit in its guidance as how to calculate (estimate) a before-tax discount factor. Nonetheless, in reality the standard implicitly requires an iterative approach. Clarification concerning a before-tax discount factor can be found in IAS 36, BC85 ${ }^{15}$. After the conclusions in BC85, an example illustrates that a before-tax discount rate can be calculated by an iterative process, so that discounting either before-tax cash flows with a before-tax discount rate or after-tax cash flows with an after-tax discount factor yield identical results. This ensures that the estimated value is the same independent of whether a before-tax or an after-tax approach is used. In other words it requires that value in use is estimated by applying an after-tax approach, followed by iteration process to find a before-tax discount factor that yields the exactly same value as the aftertax approach.

\footnotetext{
${ }^{15} \mathrm{BC}$ is basis for conclusions (labeled $\mathrm{NCZ}$ in the standard).
} 
An iterative process can only be avoided under the strict assumption that future cash flows are infinite and constant. In this special case the before-tax discount rate is calculated as the after-tax discount rate divided by the reciprocal value of the corporate tax rate $(1$ - corporate tax rate). Thus, it is not possible to calculate a discount factor that can be applied to different projects, as the iterated discount factor depend upon the distribution of the individual projects cash flows (see below and appendix A for further comments on this subject).

\begin{tabular}{|l|c|}
\hline Table 9 & Number \\
\hline Which of the following two methods do you apply for discounting cash flows? & 26 \\
\hline Discounting of before-tax cash flows with before-tax discount factor & 23 \\
\hline Discounting of after-tax cash flows with an after-tax discount factor & 5 \\
\hline Don't know / do not wish to answer & 54 \\
\hline Total & \\
\hline
\end{tabular}

Table 9 shows that approximately half of the respondents (26) choose to estimate value in use based on before-tax cash flows discounted by before-tax discount rates. The other respondents measure value in use based on an after-tax calculation. As mentioned above a before-tax valuation of a project with finite expected cash flows only provides correct value in use estimates, if a value in use calculations is applied, where the before-tax discount rate is found by the iteration procedure (where the estimated value equals the value that is estimated using the after-tax approach). The same applies for projects with infinite expected cash flows that are assumed to grow. In table 10 the respondents were asked how to transform an after-tax discount rate to a before-tax discount rate.

\begin{tabular}{|l|cc|}
\hline $\begin{array}{l}\text { Table } 10 \\
\begin{array}{l}\text { How is the after-tax discount rate transformed to a } \\
\text { before-tax discount rate? }\end{array}\end{array}$ & $\begin{array}{c}\text { Pow is the before-tax discount rate estimated } \\
\text { for projects with a definite lifetime? }\end{array}$ & $\begin{array}{c}\text { Panel B } \\
\text { estimated for projects with an indefinite } \\
\text { lifetime? }\end{array}$ \\
\hline After-tax required return / (1- corporate tax rate) & 4 & 2 \\
\hline Other adjustment of after-tax required rate of return & 1 & 1 \\
\hline By iteration & 0 & 11 \\
\hline $\begin{array}{l}\text { Investors required rate of return * equity/(equity }+ \\
\text { interest borrowing debt) + interest rate * interest } \\
\text { borrowing debt/ (equity }+ \text { interest borrowing debt) }\end{array}$ & 8 & 9 \\
\hline Don't know / do not wish to answer & 10 & 3 \\
\hline Other (please specify in the text box below) & 26 & 26 \\
\hline Total & 3 & 9 \\
\hline
\end{tabular}


Table 10 panels $\mathrm{A}$ and $\mathrm{B}$ expose that none of the respondents use the iteration method to determining the before-tax discount rate. Panel A displays that four respondents divide the after-tax discount rate with the reciprocal value of the corporate tax rate. As a result the valuation is biased, as evidenced in appendix A. The example (in appendix A) further highlights that the shorter the expected lifetime of the project, the more biased the value estimate. Based on the example the percentage difference from the theoretical correct value estimate increases from approximately $9 \%$ to almost $29 \%$, if the lifetime of the project is changed from for example 20 years to 5 years. This type of errors, thus, has a significant impact on the value estimate. Table 10 panel B uncovers that two respondents divide the after-tax discount rate with the reciprocal value of the corporate tax rate. This is only correct under the assumption that cash flows from a CGU are indefinitely and constant. The questionnaire does not reveal, however, if the cash flows that are discounted are constant making it impossible to determine if two respondents make unbiased estimates of the discount rate and, hereby, the value estimate.

Eight (11) respondents use a discount factor that disregard tax benefits associated with interest bearing debt in their WACC-calculation used for valuing projects with a finite (infinite) lifetime. This is, however, not the correct way to calculate the before-tax discount rate. This can best be exemplified by looking at firms that are $100 \%$ equity financed. For those firms equity holders' required rate of return is equal to the firm's WACC. Furthermore, the before and after-tax discount rates (WACC) are identical, as the firms do not have any tax savings from loan capital. In this scenario, expected earnings before tax and after tax will be discounted by the same (required) rate of return, which is incorrect. As a consequence the estimated value based on before-tax cash flows are biased upwards as the before-tax discount rate is too low.

The three respondents, who ticked 'other', reply that they either use a before-tax discount rate estimated by an "external investment bank" or that their firm does not have "a fixed practice for estimating the before-tax discount factor". While the latter response is basically uninformative, it indicates that the firm may not be fully aware of the issues in calculating the before-tax discount rate. Unfortunately, they do not explain how they estimate a before-tax discount factor. 


\section{Risk}

In accordance with IAS 36, 55 and 56 and appendix A15 risk specific to the asset must be accounted for by either adjusting the cash flow or the discount rate. This is in line with recommendations in prevalent corporate finance literature (e.g., Brealey and Myers, 2003), who name the two methods 'the certainty equivalent method' and 'the risk-adjusted discount rate method', respectively. Theoretically, the two methods yield identical results and choosing between the two shouldn't matter. Previous studies have shown that practitioners almost exclusively use the risk-adjusted discount rate method (Petersen et al., 2006). It is also the method that is best described in the popular valuation literature (e.g., Koller et. al 2005 and Damodaran 2002). In addition beta values, which are used to estimate the risk adjusted discount rate, are reported in financial databases like Bloomberg. Beta $(\beta)$ is measured as

$\beta=\operatorname{Cov}\left[\mathrm{r}_{\mathrm{ass}}, \mathrm{r}_{\mathrm{m}}\right] / \operatorname{Var}\left(\mathrm{r}_{\mathrm{m}}\right)$

where Cov, $r_{\mathrm{ass}}, \mathrm{r}_{\mathrm{m}}$ and Var represent covariance, return on assets, marked return and variance respectively. The certainty equivalent method estimates the cash flow that makes an investor indifferent between a certain cash flow and an uncertain cash flow in a given point of time. The certainty equivalent method requires that the cash flows are adjusted for risk. This adjustment can be shown as $\mathrm{CE}(\mathrm{CF})=\left(\right.$ Expected cash flow $\left.-\mathrm{b}\left[\mathrm{u}_{\mathrm{m}}-\mathrm{r}_{\mathrm{f}}\right]\right) . \mathrm{u}_{\mathrm{m}}$ is the expected rate of return on the market portfolio and $\mathrm{b}$ is measured as

$\mathrm{b}=\operatorname{Cov}\left[\mathrm{CF}_{\mathrm{t}}, \mathrm{r}_{\mathrm{m}}\right] / \operatorname{Var}\left(\mathrm{r}_{\mathrm{m}}\right)$.

In the following we examine how firms adjust for risk.

\begin{tabular}{|l|c|}
\hline Table 11 & No. \# \\
Where do you adjust for the risk, when you apply the DCF-model? & 8 \\
\hline The cash flows (nominator) & 31 \\
\hline Discount rate (denominator) & 16 \\
\hline Don't know / do not wish to answer & 55 \\
\hline Total & \\
\hline
\end{tabular}

Eight respondents adjust for risk in the cash flows and 31 respondents adjust for the risk in the discount rate (Table 11). IAS 36, 55-56 speaks of 'adjustments to the cash flows' without 
specifying how these adjustments should be made. Since the standard is silent as how to risk adjust for cash flows, we want to examine current practice. The results are reported in Table 12.

\begin{tabular}{|l|c|}
\hline $\begin{array}{l}\text { Table } 12 \\
\text { How do you adjust cash flows for risk, when you apply the DCF-model? }\end{array}$ & Number \\
\hline By making a conservative estimate of the free cash flows & 1 \\
\hline By weighting the likelihood of possible future cash flows & 0 \\
\hline $\begin{array}{l}\text { They expected free cash flows are reduced by multiplying them with a } \\
\text { factor calculated via the risk adjusted required rate of return (the factor } \\
\text { can for explicit budget years be estimated as follows:((1+rf)/(1+r)) } n)\end{array}$ & 1 \\
\hline They expected free cash flows reduced with a fixed percentage & 2 \\
\hline Don't know / do not wish to answer & 0 \\
\hline Other (please specify in the textbox below) & 8 \\
\hline Total & \\
\hline
\end{tabular}

Four respondents adjust for risk by measuring cash flows conservatively. While this procedure adjusts for risk, it will only by chance be unbiased. Furthermore, in practice it is unclear what 'measuring conservatively' means. What some might perceive as conservative, others might perceive as the most likely outcome. One respondent adjusts for the risk by probability weighting future cash flows. This corresponds to what IAS 36, appendix A defines as expected cash flow. This method simply weights the different likely outcomes (cash flows) and adds them. The method is proposed as an alternative to estimation of the expected cash flows rather than the most likely cash flow. A probability weighting of the different cash flows, therefore, is not the correct way to adjust for risk. One respondent reduces the expected cash flows with a fixed percentage. There is no way to tell how this percentage has been calculated, but if the same fixed percentage is used across business units that carry different risks, the adjustment for the risk is not correct. Two respondents do not inform how they adjust for risk in the cash flows.

IAS 36, 56 requires that the discount rate reflects the risk of the assets; i.e. the risk of each CGU. If the discount rate is adjusted for risk, cash flows should be discounted with the weighted average cost of capital (WACC) or a variant hereof (e.g., implicit discount factor for comparable firms) that reflects the risk of each CGU. ${ }^{16}$

\footnotetext{
${ }^{16}$ As the value for financial institutions (e.g., banks) is estimated on the equity level, the required rate of return for those kinds of firms will be the equity holders required rate of return.
} 


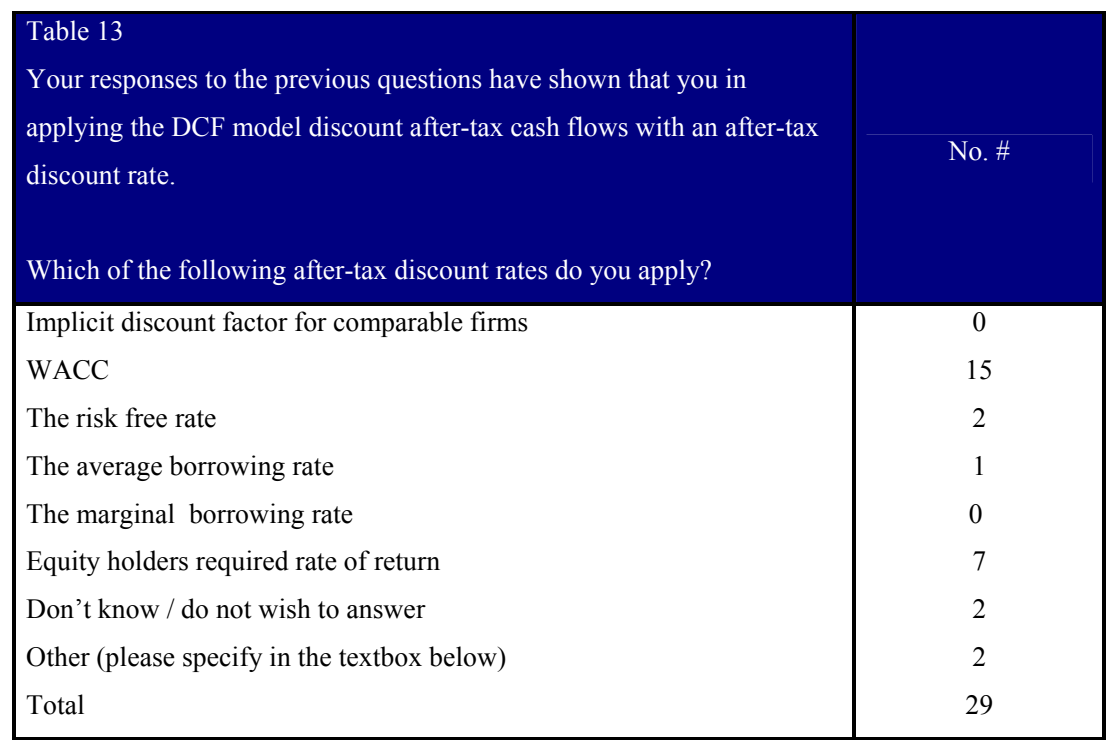

As reported in table 13 approximately half (15) of those who adjust for risk in the denominator use WACC, which is correct if the WACC reflects the risk to the specific CGU. Of the 15 respondents who use WACC, 12 use different WACC's across CGUs (not reported). They argue that this is due to the fact that business activities carry different risks, for example, due to CGUs that are situated in different parts of the world (country risk) and differences in the financial leverage in the individual CGUs. Two respondents, who argue that risk is adjusted in the discount factor, use the risk free interest rate. Clearly, the risk free rate does not take risk into account. One respondent uses the average borrowing rate. This discount factor, however, does not include equity holders required rate of return and is biased. Seven respondents use the equity holders required rate of return, three of these are financial institutions. The remaining four uses interest bearing debt as well as equity in their capital structure and should use WACC or a variant hereof as the discount rate. The two respondents, who respond 'other', use a 'combination of WACC and average rate of return on excess cash' and an 'estimated discount factor'. It is difficult to evaluate an 'estimated discount factor', while a 'combination of WACC and average rate of return on excess cash' is incorrect. Of the 27, who respond, which discount factor they use, at least eight use a discount factor not supported by theory. Considering how well this area is portrayed in the finance literature, the results came as a surprise (to us). 
The length of the budget period and determining terminal value

IAS 36, 33 states that "projections based on these budgets/forecasts shall cover a maximum period of five years, unless a longer period can be justified". The intention is to limit the number of explicit budget years, prior to the terminal period.

\begin{tabular}{|l|c|}
\hline Table 14 & \\
$\begin{array}{l}\text { Do you use the same number of budget years in all CGUs, when you } \\
\text { apply discounted cash flow calculations for impairment testing } \\
\text { purposes? }\end{array}$ & Number \\
\hline Yes & 41 \\
\hline No & 9 \\
\hline Don't know / do not wish to answer & 5 \\
\hline Total & 55 \\
\hline
\end{tabular}

According to Table 14, 41 respondents use the same budget period for all CGUs, while nine respondents use different budget periods across CGUs. Out of the 41 respondents, who use the same budget period across CGUs, 19 use a budget period of 5 years (not reported), while five respondents use a 10 year budget period. The other respondents use a budget period ranging from 1 to 4 years. As decisive factors for choosing the length of the budget period, the respondents pointed to the ability to create abnormal profit and the life cycle of the CGUs. Furthermore, some of the respondents mentioned that the number of years in the budget period was based on what seems reasonable and was inspired by the firm's general budget routines. Thus, the choice of the explicit budget period seems to be well founded and in accordance with IAS 36 . 


\begin{tabular}{|c|c|c|c|c|c|c|}
\hline \multirow{3}{*}{\multicolumn{2}{|c|}{\begin{tabular}{|l} 
Table 15 \\
Terminal calculations
\end{tabular}}} & \multicolumn{5}{|c|}{$\begin{array}{l}\text { How many years into the terminal period do } \\
\text { you budget explicitly? }\end{array}$} \\
\hline & & & & & & \\
\hline & & 0 & 1 & $\begin{array}{l}2 \text { or } \\
\text { more }\end{array}$ & $\begin{array}{l}\text { do not } \\
\text { wish to } \\
\text { answer }\end{array}$ & Total \\
\hline \multirow{7}{*}{ 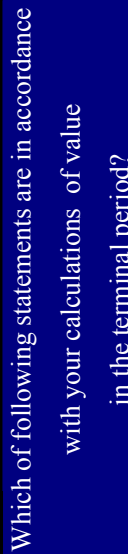 } & $\begin{array}{l}\text { Free cash flows in terminal period grow with a constant growth rate every year = } \\
\text { FCF/(WACC-g), (Gordon's growth model) }\end{array}$ & 11 & 7 & 9 & 1 & 28 \\
\hline & $\begin{array}{l}\text { Growth in the terminal period does not create value } / \text { free cash flows in the terminal } \\
\text { period does not grow = NOPAT/WACC, (convergence model) }\end{array}$ & 4 & 1 & 1 & & 6 \\
\hline & $\begin{array}{l}\text { Return on invested capital is different from cost of capital in the terminal period }= \\
\left(\text { NOPAT }^{*}(1-\mathrm{g} / \text { ROIC })\right) /(\text { WACC-g), (Value driver formula) }\end{array}$ & & 1 & 2 & & 3 \\
\hline & We use multiples & 1 & & 1 & & 2 \\
\hline & Other (please specify below) & 1 & & & & 1 \\
\hline & Don’t know / do not wish to answer & 2 & 3 & 4 & 3 & 12 \\
\hline & Total & 19 & 12 & 17 & 4 & 52 \\
\hline
\end{tabular}

IAS 36 does not provide any guidance as to which method(s) to use in estimating the terminal value. Table 15 shows that 28 respondents apply Gordon's growth model, while three respondents use the value driver formula (i.e. 31 respondents assume growth in the terminal period). Six respondents assume that growth do not create value in the terminal period and, thus, use the convergence model. These results match the ones reported in Petersen et al. (2006). They find that professional investors and financial advisers generally assume growth in estimating terminal value. Two respondents use multiples to estimate terminal value. While this is not ruled out in IAS 36, it is a violation of the DCF model. As presumable $70 \%$ or more of the estimated value can be attributed to the terminal value, most of the value estimate is captured by the multiple. It is therefore an open question if the respondents who use multiples in essence apply a DCF model.

A prerequisite for a proper application of estimating terminal value is that the estimated expected start-of-terminal-period cash flow is indicative of the future cash flow generation. Therefore a firm must have reached the so called "steady state", where all parameters that decide future cash flows (turnover, expenses, invested capital etc.) have reached the same level of growth. The only way to assure this is to budget the free cash flow, based on the income statement and balance sheet, (at least) one year into the terminal period (Lundholm and O'Keefe, 2001). The logic behind this can be illustrated by the following simplified example. Assume a firm has a free cash flow of 100 in the 
final year of the explicit forecast period. Growth in that year was an estimated $6 \%$. In the terminal period growth is assumed to be $2 \%$. It might be tempting to calculate the free cash flow for the first year in the terminal period as $100 * 1.02=102$. As growth is decreasing less cash is tied in working capital and fixed assets, and the level of free cash is shifted upward, so that it is in excess of $102 .{ }^{17}$ It is not unusual that the free cash flow is $30-40 \%$ higher than the 102. If growth is assumed in calculating terminal values, the consequences for the value estimate will be significant, if a firm do not make an explicit budget for the first year of the terminal period in estimating the free cash flow. ${ }^{18}$ This is also pointed out by Levin and Olsson (2000) who argue: “...even minor internal inconsistencies can have a substantial impact on the final value estimate of a company."

If the convergence model is applied, it is assumed that depreciations (and amortisations) match reinvestments, which is why net operating profit after tax (NOPAT) is used as an estimate for the free cash flow. In such cases it is typically not necessary to budget into the terminal period. NOPAT for the last explicit budget year is representative for future earnings (cash flows). Only in the special case, where depreciations are a poor estimate for reinvestments, is it necessary to budget explicitly into the terminal period or make adjustments to depreciations. It is typically the case, if significant investments have been made prior to the last budget year. In summary, firms should budget 1-2 years into the terminal period, if they use Gordon's growth model.

In Table 15 the choice of terminal value model is paired with number of years budgeted into the terminal period. This pairing is made to highlight, whether respondents, who apply Gordon's growth model, make explicit forecast into the terminal period. As seen in the table, 11 out of 28 respondents do not explicitly forecast into the terminal period. The consequence is that the free cash flow that terminal value estimation is based on is most likely biased. It may at the same time have significant effect on the value estimate. It is difficult to give an unequivocal answer on the other crossing, but generally the judgment is that the free cash flow/NOPAT that are used as a basis for the respective terminal value models, are estimated correctly.

\footnotetext{
${ }^{17}$ It might be discussed if the same profit margin can be sustained if the growth rate is lower. However, this is irrelevant for the example.

${ }^{18}$ If lagged budget assumptions are used (e.g., depreciations based on the beginning of the period fixed assets), it might be necessary to budget two years into the terminal period in order to determine the free cash flow (Petersen and Plenborg (2006)).
} 
Valuation of firms is not an exact science. Value estimates are affected by a large number of judgments and a budget that often assumes infinite lifetime for the CGU. That is why it is appropriate to carry out sensitivity analyses that measure the effect on value estimates of changes in major assumptions.

\begin{tabular}{|l|c|}
\hline Table 16 & No. \# \\
Do you carry out any kind of sensitivity analysis in estimating value in \\
use?
\end{tabular}

Table 16 uncovers how many respondents who make sensitivity analyses. 32 apply sensitivity analyses, while 14 do not. Based on the feedback it is unclear, if the lack of sensitivity analyses reflects that there is no need to verify the valuation or if it is simply not a routine in relation to impairment tests. They respondents, who choose to carry out a sensitivity analyses, recognise impairment losses (in the income statement), if a certain percentage (typically over 50\%) of the simulated scenarios indicate a need to write-off (not reported).

\section{Conclusions and perspectives}

We examine how firms define a CGU and how those firms measure the recoverable amount of a CGU adopting a survey approach. A risk inherent in surveys is that the respondents are not representative of the population and that the questions may be misunderstood. We put considerable effort into reducing those risks. As a result we obtained a high response rate (more than 70\%) and received feedbacks from respondents, who are deeply involved in carrying out impairment tests. Our survey generally supports that a common practice has not yet been established. Based on our analysis is difficult to say whether this simply reflects that firms adopt an approach suited to their organisational and economic structures or it suggests that firms are uncertain as how to apply the standard. We also find that some firms do not define a CGU in compliance with IAS 36. A few firms operate with fewer CGUs than segments, which is a violation of IAS 36, 80b. Some firms also argue that they choose the number of CGUs based on the wish to reduce the number of write-offs, which is a violation of IAS 36,80 . Twenty firms do not include corporate assets in a CGU for impairment testing purposes, which is a violation of IAS $36,102$. 
Further, we find inconsistencies in the way that firms estimate the recoverable amount. None of the firms used the iteration method to transform an after-tax discount rate to a before-tax discount rate. Firms also experience difficulties in risk adjusting cash flows and discount rates. The estimation of the free cash flow in the terminal period is another area of concern. Finally, a few firms do not use multiples properly.

Since IAS 36 was adopted in March 2004 the responses in our survey are obtained from respondents that (in many cases) have limited experience with impairment tests of goodwill. It may, therefore, be premature to draw any strong conclusions based on our results. However, we still believe that our results should be of interest. Firms may use our findings to improve the way that they carry out impairment tests. Auditors may use our results to focus on areas that deserve further attention. Standard setters may want to evaluate the current standard and consider how improve it. For example, a follow through example that clearly explains how the value of a CGU is estimated based on a before-tax/after-tax basis and how to adjust for risk in the cash flow and discount rate, respectively, would be useful.

This study may benefit extended by considering the following issues. It is obvious to analyse, what characterises firms that have most difficulties in implementing complicated standards (e.g., IFRS/IAS3). Such research may be beneficial as help and resources can be directed towards firms that find it difficult to implement new standards. Research could also be extended to other accounting items with a similar complexity. Provisions, stock options and financial instruments are some of the accounting items, which deserve to be further researched. It also seems appropriate to examine how users of financial statements read, interpret and use accounting information, including challenging accounting items such as write-offs of goodwill. This is also supported by the fact that new and more complex accounting standards keep coming. A recent research project in Norway (Kinserdal, 2006) documented that financial analysts do not properly consider that pension liabilities in Norwegian firms are valued differently (based on different assumptions). Such results may question, whether or not financial analysts use all value relevant accounting information in valuation of firms. 


\section{Literature}

Anderson, N. (2004): Financial Reporting: Implementing IFRS 3 and IAS 38 - Value judgments, Accountancy, Vol. 13 (4).

Banghøj, J and Plenborg, T. (2007): The value relevance of voluntary disclosure in the annual report, Accounting and Finance, forthcoming.

Brealey and Myers (2003), Principles of Corporate Finance, $7^{\text {th }}$ edition, McGraw-Hill

Bugeja, M., Gallery, N. (2006), Is older goodwill value relevant?, Accounting and Finance, Vol. 46 (4)

Colquitt, L. and Wilson, A. (2002), The Elimination of Pooling-of-Interests and Goodwill Amortisation and its Effect on the Insurance Industry, Journal of Insurance Regulation, Vol 20 (3)

Damodaran, A. (2002): Investment Valuation, $2^{\text {nd }}$ edition, Wiley

Donnelly, T and Keys, R (2002), Business Combinations and Intangible Assets, Australian CPA, Vol $72(4)$

Ernst \& Young (2006): IFRS i praksis 2006 - Udvalgte områder med fokus på præsentation

Graham, J. R. and Harvey C. R. (2001). "The theory and practice of corporate finance: evidence from the field", Journal of Financial Economics, 60, 187-243.

Henning, S.L., Lewis, B.L and Shaw, Wayne H. S. (2000): Valuation of the Components of Purchased Goodwill, Journal of Accounting Research, Vol. 38 (2)

IASB (2004), IFRS 3: Financial Reporting Standards Business Combinations, International Accounting Standards Board

IASB (2004), IFRS 3: Financial Reporting Standards Business Combinations, Basis for Conclusions, International Accounting Standards Board

IASB (2004), IAS 36: International Accounting Standards 36 Impairment of Assets, International Accounting Standards Board

IASB (2004), IAS 36: International Accounting Standards 36 Impairment of Assets, Basis for Conclusions, International Accounting Standards Board

Jansson T., Nilsson, J, and Rynell T. (2004), Redovisning av företagsförvärv enligt IFRS innebär omfattande och väsentliga förändringar, Balans 8-9. 
Jennings, R., LeClere M. and Thompson, R. B. (2001): Goodwill Amortisation and the Usefulness of Earnings, Financial Analysts Journal Vol. 57 (5)

Kinserdal, F., (2006): Accounting for and valuation of pensions in Norway - earnings management whether analysts detect, Ph.D. dissertation, (NHH)

Koller, T., M Goedhardt and D. Wessels (2005): Valuation - measuring and managing the value of companies, $4^{\text {th }}$ edition, Wiley $\&$ Sons

Launsø, L. and O. Rieper (2000): Forskning om og med mennesker, Nordisk Forlag Arnold Busck

Lachnit, L. and Müller, S. (2003), Bilanzanalytische Behandlung von Geschäfts- oder Firmenwerten, Zeitschrift für Kapitalmarktorientierte Rechnungslegung, Vol 3 pp. $540-550$

Levin, J. and P. Olsson (2000): Terminal Value Techniques In Equity Valuation - Implications of the Steady State Assumption, Working Paper, Stockholm School of Economics

Lundholm, R. and T. O'Keefe. (2001). Reconciling value estimates from the discounted cash flow model and the residual income model. Contemporary Accounting Research, 18 (Summer): 311-335.

McGreachin, A. (1997), Bringing Impairment Under One Umbrella, Accountancy, Vol 120 (1247)

Petersen, C. and T. Plenborg (2006): The implementation and application of valuation approaches, working paper, Copenhagen Business School

Petersen, C., T. Plenborg and F. Schøler (2006): Issues In valuation of privately held companies, Journal of Private Equity

Ravlic, T. (2003), Goodwill Hunting, Australian CPA, April Issue

Rockness, J. W., Rockness, H. O. and Ivancevich, S. H. (2001), The M and A Game Changes, Financial Executive, Vol 1 (7)

Stevenson, H. and McPhee, D. (2005), Acquiring companies: knowing your IAS from your elbow, accountancymagazine.com

Yin, R. K. (1994), Case Study Research: Design and methods, Sage, $2^{\text {nd }}$ edition. 


\section{Appendix A}

The following examples show the consequences of calculating the before-tax discount rate as the after-tax discount rate / $(1-$ the corporate tax rate) inconsistent with the recommended iteration method in IAS 36.

In the first example infinite lifetime is assumed, while the second example assumes finite lifetime.

\section{Example 1: Infinite lifetime}

In the first example the required rate of return after tax (WACC) is assumed to be $10 \%$, growth in both the explicit budget and terminal period is $3 \%$ and the corporate tax rate is $30 \%$. Finally, it is assumed that the free cash flow (FCF) after tax is 10.00 in the first forecast year.

\section{Example, indefinite lifetime}

WACC (discount rate after tax)

Growth in budget period

$10,00 \%$

$3,00 \%$

Growth i terminal period

Tax rate

Free cash flow before tax

Tax

Free cash flow after tax
$3,00 \%$

$30,00 \%$

14,29

$-4,29$

10,00

10,00

0,9091

9,09

33,04

109,82

142,86

\section{After tax calculation}

Discount factor

PV FCF

Present value of $\mathrm{FCF}$

Present value of FCF - terminal period

Estimated value

$\frac{109,82}{142,86}$

\section{Before tax calculation [WACC/(1-tax rate)]}

Free cash flow before tax

Discount factor

Discount factor, before tax

PV FCF

Present value of FCF

14,29

14,71

15,16

15,61

16,08

Present value of FCF - terminal period

Estimated value

$14,29 \%$

0,8750

0,7656

0,6699

0,5862

12,50

11,27

10,15

9,15

\section{Iteration}

Free cash flow before tax

Discount factor (unknown)

Discount factor, before tax

PV FCF

43,07

83,51

126,58

Present value of FCF

14,29

$13,00 \%$

0,8850

12,64

44,24

Present value of FCF - terminal period

Estimated value

98,61

$\begin{array}{rrr}14,71 & 15,16 & 15,61 \\ 0,7831 & 0,6931 & 0,6133 \\ 11,52 & 10,50 & 9,57 \\ & & \end{array}$

Terminal

period

16,08

$-4,82$

11,26

11,26

10,93

7,46

As growth is the same in the forecast period and the terminal period, is it not necessary to operate with two forecast periods. This assumption is kept, however, as in practice most operate with a budget period as well as a terminal period. In the example the budget period is four years. Under the specified budget assumptions, the discount rate is $9.8 \%$ is too high $(14.29 \%$ against $13.00 \%)$. As a result the value is $11.4 \%$ too low (126.58 against 142.86 ). 
In the next table the same budget assumptions are applied except of the growth rate. This is assumed to vary from $0 \%$ to $6 \%$ in all future periods (contrary to $3 \%$ in the example above).

\begin{tabular}{lrrrrrr} 
Growth & $\mathbf{0 \%}$ & $\mathbf{1 \%}$ & $\mathbf{2 \%}$ & $\mathbf{3 \%}$ & $\mathbf{4 \%}$ & $\mathbf{5 \%}$ \\
\hline Wrong discount rate before tax & $14,28 \%$ & $14,28 \%$ & $14,28 \%$ & $14,28 \%$ & $14,28 \%$ & $14,28 \%$ \\
Correct discount rate before tax & $14,28 \%$ & $13,86 \%$ & $13,42 \%$ & $13,00 \%$ & $12,57 \%$ & $12,14 \%$ \\
\hline Discount rate, percentage change & $\mathbf{0 , 0 \%}$ & $\mathbf{3 , 0 \%}$ & $\mathbf{6 , 4 \%}$ & $\mathbf{9 , 8} \%$ & $\mathbf{1 3 , 6 \%}$ & $\mathbf{1 7 , 6 \%}$ \\
\hline Value correct discount rate & 100,00 & 111,11 & 125,00 & 142,86 & 166,67 & 200,00 \\
Value wrong discount rate & 100 & 107,53 & 116,28 & 126,58 & 138,89 & $\mathbf{1 5 3 , 8 5}$ \\
Value, percentage change & $\mathbf{0 , 0 \%}$ & $\mathbf{- 3 , 2 \%}$ & $\mathbf{- 7 , 0 \%}$ & $\mathbf{- 1 1 , 4 \%}$ & $\mathbf{- 1 6 , 7 \%}$ & $\mathbf{- 2 3 , 1 \%}$ \\
\hline
\end{tabular}

As seen from the table, a before-tax discount rate calculated as

After-tax discount factor / (1- the corporate tax rate)

will only prove correct, assuming no growth in all future periods (growth $=0 \%$ ). Under other growth assumptions, the discount rate before-tax and hereby the estimated net present value (recoverable amount) is biased. The higher the assumed future growth, the more biased the estimated net present value.

\section{Example 2: Finite lifetime}

In the following example finite lifetime is assumed for a project ( 5 years respectively 20 years) that is valued. FCF in the first budget year is 100 and the after-tax discount rate is $10 \%$. Further, growth in the lifetime of the project varies form $-5 \%$ to $5 \%$ p.a. Under these assumptions it is evident that the shorter the lifetime of the project, the higher the impact from the before-tax discount rate estimated as

After-tax discount factor / (1- the corporate tax rate)

Assuming zero growth in the FCF and a five-year project lifetime the before-tax discount rate is undervalued by $44.3 \%(14.29 \%$ against $25.66 \%)$. As a consequence the project is overvalued by $28.5 \%$ (487 against 379 ). The example further illustrates the effect of the error if the projects lifetime increases from five years to 20 years. It demonstrates that the shorter the lifetime of the project, the greater the effect of the miscalculated before-tax discount factor on value in use. Growth has an effect on, as evident from the example, the bias introduced by applying a wrong before-tax discount factor. This is hardly surprising $\mathrm{cf}$. the example with infinite lifetime 
Example, finite lifetime

Free cash flow aftyer tax, 1. budget year 100

Discount rate after tax

Example, finite lifetime

Lifetime of the project, years

$\begin{array}{llllll}5 & 20 & 5 & 20 & 5 & 20\end{array}$

Growth in FCF p.a.

$0 \% \quad 0 \% \quad 5 \% \quad 5 \% \quad-5 \% \quad-5 \%$

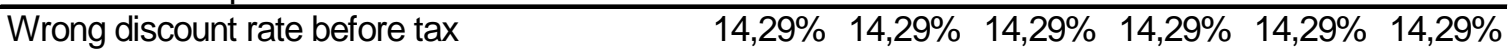

Correct discount rate before tax

\begin{tabular}{lllllll}
$25,66 \%$ & $15,90 \%$ & $25,06 \%$ & $14,82 \%$ & $26,32 \%$ & $17,30 \%$ \\
\hline
\end{tabular}

Discount rate, change in percent

\begin{tabular}{llllll}
$-44,3 \%$ & $-10,1 \%$ & $-43,0 \%$ & $-3,6 \%$ & $-45,7 \%$ & $-17,4 \%$ \\
\hline
\end{tabular}

Value, correct discount rate

$\begin{array}{llllll}379,08 & 851,36 & 415,06 & 1211,2 & 346,36 & 631,14\end{array}$

Value, wrong discount rate

\begin{tabular}{rrrrrr}
487,09 & 930,79 & 531,36 & 1256 & 446,76 & 722,36 \\
\hline
\end{tabular}

Value, change in percent

\begin{tabular}{lllllll}
$28,5 \%$ & $9,3 \%$ & $28,0 \%$ & $3,7 \%$ & $29,0 \%$ & $14,5 \%$ \\
\hline
\end{tabular}

